

\section{DISCLAIMER}

This report was prepared as an account of work sponsored by an agency of the United States Government. Neither the United States Government nor any agency Thereof, nor any of their employees, makes any warranty, express or implied, or assumes any legal liability or responsibility for the accuracy, completeness, or usefulness of any information, apparatus, product, or process disclosed, or represents that its use would not infringe privately owned rights. Reference herein to any specific commercial product, process, or service by trade name, trademark, manufacturer, or otherwise does not necessarily constitute or imply its endorsement, recommendation, or favoring by the United States Government or any agency thereof. The views and opinions of authors expressed herein do not necessarily state or reflect those of the United States Government or any agency thereof. 


\section{DISCLAIMER}

Portions of this document may be illegible in electronic image products. Images are produced from the best available original document. 
Reference to a company or product name does not imply approval or recommendation of the product by Union Carbide Corporation or the Department of Energy to the exclusion of others that may meet specifications.

\section{Printed in the United States of America. Available from National Technical Information Service \\ U.S. Department of Commerce 5285 Port Royal Road, Springfield, Virginia 22161 \\ Price: Printed Copy $\$ 4.00$; Microfiche $\$ 3.00$}

This report was prepared as an account of work sponsored by an agency of the United States Government. Neither the United States Government nor any agency thereof. nor any of their employees, nor any of their contractors, subcontractors, or their employees, makes any warranty, express or implied, nor assumes any legal liability or responsibility for any third party's use or the results of such use of any information, apparatus, product or process disclosed in this report, nor represents that its use by such third party would not infringe privately owned rights. 
Form ERDA 426

$(2 \pi 5)$

ERDAM 3201

\section{U.S. ENERGY RESEARCH \& DEVELOPMENT ADMINISTRATION \\ MAJOR CONTRACTOR'S RECOMMENDATION FOR \\ DISPOSITION OF SCIENTIFIC AND TECHNICAL DOCUMENT}

* See Instructions on Reverse

1. ERDA Report No. $\mathrm{Y}-2135$

2. Subject Category No. UC-25, Materials

4. Type of Document (" $X$ " one)

a. Scientific and Tecnnical Report

b. Conference paper:

Title of conference

Date of conference

Exact location of conference
3. Title

Fabrication and Characterization of Uranium-6 Niobium Alloy P1ate with Improved Homogeneity

c. Other (Specify, Thesis, Translation, etc.)*

5. Copies Transmitted (" $X$ " one or more)

a. Copies being transmitted for standard distribution by ERDA-TIC.

$\square$ b. Copies being transritted for special distribution per attached complete address list.*

$\square$ c. Two completely legible, reproducible copies being transmitted to ERDA-TIC.

6. Recommended Distribution (" $X$ " one)

X] a. Normal handling (after Patent clearance): no restraints on distribution except as may be required by the security classification.

$\square$ b. Make available only to U.S. Government agencies and their contractors.

[c. Make available only within ERDA and to ERDA contractors.

$\square$ d. Make available only within ERDA.

$\square$ e. Make available only to those listed in item 12 below.

f. Other (Specify)*

7. Recommended Announcement " " $X$ " one)

X] a. Normal procedure may be followed.*

$\square$ b. Recommend following announcement limitations:

8. Reason for Restrictions Recommended in 6 or 7 above.

$\square$ a. Preliminary information.

b. Prepared primarily for internal use.

$\square$ c. Other (Explain)

9. Patent Clearance (" $X$ " one)

[ a. ERDA patent clearance has been granted by responsible ERDA patent group.

b. Document has been sent to responsible ERDA patent group for clearance.

10. National Security Information (For classified document only; " $X$ " one)

$\square$ a. Document does contain national security Information other than restricted data.

$\square$ b. Document does not contain national security information other than restricted data.

11. Copy Reproduction and Distribution

a. Total number of copies reproduced See Distribution

b. Number of copies distributed outside originating organization

12. Additional information or Remarks (Continue on separate sheet, if necessary).

13. Submitted by (Name and Position) (Please print or type)*

J. M. Mil1s, Jr., Assistant Information Control officer

14. Organization

Union Carbide Corporation, Nuclear Division, Oak Ridge Y-12 Plant, Oak Ridge, TN

15. Signature M MI: 16. Date August 22, 1978 


\section{INSTRUCTIONS}

Who uses this Form: All ERDA contractors except those specifically instructed by their ERDA contract administrator to use the shorter Form ERDA=427.

When to Use: Submit one copy of this Form with each document which is sent to ERDA's Techncial Information Center (TIC) in accordance with the requirements of ERDA Manual Chapter 3201.

Where to send: Forward this Form and the document(s) to:

USERDA-TIC

P.O. Box 62

Oak Ridge, TN 37830

Item instructions:

Item 1. The first element in the number shall be an ERDAapproved code to be determined as follows: (a) The responsible field office may request TIC approval of a unique code for a contractor, e.g., BNL, BMI, HNL, etc.; (b) A program division may request TIC approval of a unique code for a program or series of reports, e.g., PNE, VUF, etc.; (c) An operations office may instruct a contractor to use the code approved for the operations office, i.e., COO, ORO, IDO, SRO, SAN, ALO, RLO, NVO; and (d) Program divisions shall use the code ERDA for reports which they themselves prepare unless there is reason to use some other approved code.

The code shall be followed by a sequential number, or by a contract number plus a sequential number, as follows: (a) Contractors or programs with unique codes may complete the report number by adding a sequential number to the code, e.g., HNL-101, HNL-102, etc.; or PNE-1, PNE-2, etc.; or they may add the identifying portion of the contract number and a sequential number, e.g., ABC-2105-1, $\mathrm{ABC}-2105-2$, etc; (b) Contractors using the operations office code shall complete the report number by adding the identifying portion of the contract number and a sequential number, e.g., COO-2200-1, COO-2200-2, etc.; (c) Subcontractor reports shall be identified with the code used by the prime contractor; and (d) Program divisions using the ERDA code shall complete the report number by adding a sequential number which they request from the Library Branch, Division of Administrative Services.

Item 2. Insert the appropriate subject category from TID-4500 ("Standard Distribution for Unclassified Scientific and Technical Reports") or M-3679 ("Standard Distribution for Classified Scientific and Technical Reports") for both classified and unclassified documents, whether or not printed for standard distribution.

Item 3. Give title exactly as on the document itself unless title is classified. In that case, omit title and state "classified title" in the space for item 3.

Item 4. If box c is checked, indicate type of item being sent, e.g., thesis, translation, etc.

Item 5. a. If box a is checked, the number of copies specified for the appropriate category or categories in $\mathrm{M}-3679$ or TID-4500 shall be forwarded to TIC for distribution.

b. If box $b$ is checked, complete address list must be provided TIC. c. If box c is checked, at least one copy shall be original ribbon or offset and be completely legible. A clear carbon copy is acceptable as a second reproducible copy.

Item 6. If box a is checked for an unclassified document, it may be distributed by TIC (after patent clearance) to addressees listed in TID-4500 for the appropriate subject category, to libraries in the U.S. and abroad, which through purchase of microfiche maintain collections of ERDA reports, and to the National Technical Information Service for sale to the public.

If box a is checked for a classified document, it may be distributed by TIC to addressees listed in M-3679 for the appropriate subject category.

If a box other than a is checked, the recommended limitation will be followed unless TIC receives other instructions from the responsible ERDA program division

Box $f$ may be checked in order to specify special instructions, such as "Make available only as specifically approved by the program division," etc.

Item 7. a. Announcement procedures are normally determined by the distribution that is to be given a document. If box a in item 6 is checked for an unclassified document, it will normally be listed in the weekly "Accessions of Unlimited Distribution Reports by TIC" (TID-4401) and may be abstracted in "Nuclear Science Abstracts" (NSA).

A classified document, or an unclassified document for which box $b, c, d, e$, or $f_{3}$ in item 6 is checked, may be cited with appropriate subject index terms in "Abstracts of Limited Distribution Reports" (ALDR).

b. If the normal announcement procedures described in $7 \mathrm{a}$ are not appropriate check $7 \mathrm{~b}$ and indicate recommended announcement limitations.

Item 8. If a box other than a is checked in item 6 , or if $7 \mathrm{~b}$ is checked, state reason for the recommended restriction, e.g., "preliminary information," "prepared primarily for internal use," etc.

Item 9. It is assumed that there is no objection to publication from the standpoint of the originating organization's patent interest. Otherwise explain in item 12

Item 10. If box a is checked, document cannot be made available to Access Permit holders (Code of Federal Regulations, 10 CFR, Part 25, subpart 25.6); if box $b$ is checked, TIC will determine whether or not to make it available to them.

Item 11. Self explanatory.

Item 12. Use this space if necessary to expand on answers given above, e.g., item $6 f$ and item 8 .

Item 13. Enter name of person to whom inquiries concerning the recommendations on this Form may be addressed.

Item 14-16. Self explanatory. 


\title{
FABRICATION AND CHARACTERIZATION OF URANIUM-6 NIOBIUM ALLOY PLATE WITH IMPROVED HOMOGENEITY
}

\author{
W. B. Snyder \\ Metallurgy Department \\ $Y-12$ Development Division
}

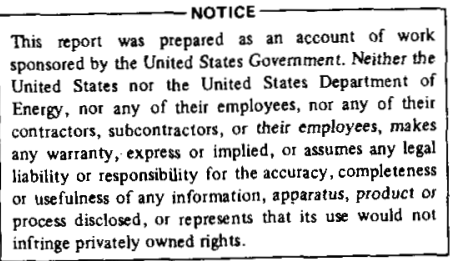

Oak Ridge $Y-12$ Plant

P. O. Box Y, Oak Ridge, Tennessee 37830

Prepared for the Department of Energy Under US Government Contract W-7405-eng-26 


\begin{abstract}
Chemical inhomogeneities produced during arc melting of uranium- 6 weight percent niobium alloy normally persist during fabrication of the ingot to a finished product. The present investigation was directed toward producing a more homogeneous product ( $13.0-\mathrm{mm}$ plate) by a combination of mechanical working and homogenization. Ingots were cast, forged to various reductions, homogenized under different conditions, and finally rolled to $13.0-\mathrm{mm}$-thick plate. It was concluded that increased forging reductions prior to homogenization resulted in a more homogeneous plate. Comparison of calculated and experimentally measured niobium concentration profiles indicated that the activation energy for the diffusion of niobium in uranium-niobium alloys may be lower than previously observed.
\end{abstract}




\section{CONTENTS}

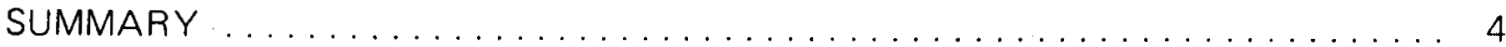

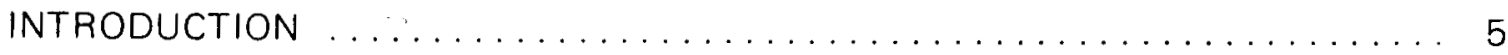

FABRICATION AND CHARACTERIZATION OF URANIUM-6 NIOBIUM ALLOY PLATE WITH IMPROVED HOMOGENEITY ................ 6

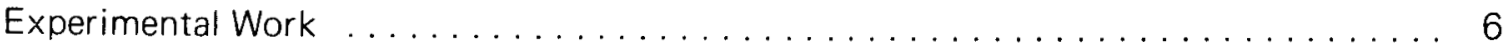

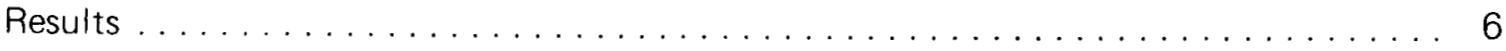

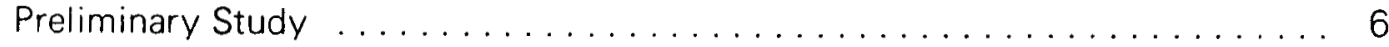

Large-Scale Study . . . . . . . . . . . . . . . . . . . . . . . . . . . . . . 9

Discussion of Results . . . . . . . . . . . . . . . . . . . . . 18

Observed Microstructure ......................... 18

Comparison to the Model . . . . . . . . . . . . . . . . . . . . . . . . . . . . . . 19

Conclusions ................................... 20

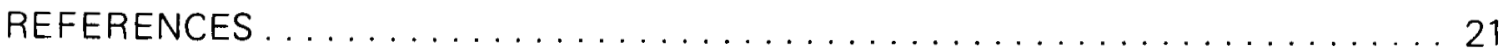




\section{SUMMARY}

The purpose of this study was to determine if more chemically homogeneous plate of the uranium- 6 weight percent niobium alloy could be produced by a combination of mechanical working and homogenization. Ingots were cast, forged to various reductions, homogenized under different conditions, and finally rolled to $13.0-\mathrm{mm}$-thick plate. Conclusions were that increased forging reductions prior to homogenization produced a more homogeneous plate. Comparison of calculated and experimentally measured niobium concentration profiles indicated that the activation energy for the diffusion of niobium in uranium-niobium alloys may be lower than previously observed. 


\section{INTRODUCTION}

Prior analyses of arc-cast uranium-6 weight percent niobium alloy ( $\mathrm{U}-6 \mathrm{Nb}$ ) billets have shown a considerable degree of both micro and macrosegregation present in the ingots. ${ }^{1}$ Homogenization studies conducted on as-cast material showed that microsegregation could be adequately reduced by homogenizing the ingot for either six hours at $1100^{\circ} \mathrm{C}$ or ten hours at $1050^{\circ} \mathrm{C}$. These treatments, however, have essentially no effect on the macrosegregation (or banding) observed in the cast ingots. A model developed during the course of the homogenization experiments predicted that forging prior to homogenization should minimize the banding effects. The present experiment, conducted at the Oak Ridge Y-12 Plant, (a) was designed to investigate the effects of forging and homogenizing treatments on the homogeneity of U-6 Nb plate.

High-temperature $\left(>1050^{\circ} \mathrm{C}\right)$ nomogenization produces a very large grain size. Without grain growth, the ideal means of producing homogeneous plate would be to forge and roll the plate to its final thickness (obtaining maximum reduction), and then homogenize. Because of grain growth it was necessary to consider a process which allowed a grain-refining step before final heat treating of the U-6 Nb plate.

(a) Operated by the Union Carbide Corporation's Nuclear Division for the Department of Energy. 


\section{FABRICATION AND CHARACTERIZATION OF URANIUM-6 NIOBIUM ALLOY PLATE WITH IMPROVED HOMOGENEITY}

\section{EXPERIMENTAL WORK}

A preliminary set of experiments determined the extent of cold rolling, warm rolling, or hot rolling necessary for subsequent recrystallization of large-grained, homogenized plate. Plate for this experiment was produced by vacuum arc melting, forging, and round rolling a $150-\mathrm{mm}$-long by $150-\mathrm{mm}$-diameter recycle billet according to standard Oak Ridge Y-12 Plant practices. Specimens $(50.0 \times 62.5 \mathrm{~mm})$, cut from this $14.4-\mathrm{mm}$-thick plate, were homogenized for twelve hours at $1175^{\circ} \mathrm{C}$ in a vacuum of $<7 \times 10^{-3} \mathrm{~Pa}$. After homogenizing, all specimens were heat treated for one hour at $800^{\circ} \mathrm{C}$ in a vacuum of $<7 \times 10^{-3} \mathrm{~Pa}$ and water quenched. Specimens were cross rolled to various reductions at room temperature, $200^{\circ} \mathrm{C}$, and $800^{\circ} \mathrm{C}$, and subsequently annealed for one hour at $800^{\circ} \mathrm{C}$ in a vacuum of $<7 \times 10^{-3} \mathrm{~Pa}$ and water quenched. The extent of recrystallization of each rolled specimen was determined by optical metallography of a mounted-specimen cross section.

Based on the results obtained on the specimens, a second set of large plates was produced by forging 150 by $150-\mathrm{mm}$-diameter billets (from recycle ingots) to various reductions, homogenizing, and round rolling either hot at $850^{\circ} \mathrm{C}$ from a molten salt bath or warm at $200^{\circ} \mathrm{C}$ from an argon furnace. After final heat treating of these plates for one hour at $800^{\circ} \mathrm{C}$ and water quenching, metallographic specimens were cut from the edge and center of each plate and mounted in epoxy such that a surface normal to the rolling direction was exposed. Electron microprobe scans were made along the thickness dimension of all plate specimens at intervals of $10 \mu \mathrm{m}(1500 \mu \mathrm{m}$, total scan) and $50 \mu \mathrm{m}(7500 \mu \mathrm{m}$, total scan). At each data point, the niobium $L_{\alpha}$ radiation was counted for thirty seconds. Calculations and plots of theoretical-concentration profiles were made by using a Hewlett Packard 9821 A computer and 9862 plotter. Grain-size estimates were made by using the untwinned ASTM grain-size charts.

\section{RESULTS}

\section{Preliminary Study}

A summary of the results that were obtained from rolling the small $(14.4 \times 50.0 \times 62.5-\mathrm{mm})$ homogenized specimens will be given first, then the data from the processing of full-sized plates will be presented later. A view of the microstructure of a small specimen after homogenizing for 12 hours at $1175^{\circ} \mathrm{C}$, followed by solution heat treating for one hour at $800^{\circ} \mathrm{C}$ and water quenching, is given in Figure 1. The large grain size (ASTM 00) illustrates the need for a grain-refining step prior to final heat treatment. Three of the specimens were cold rolled on the Metallurgical Development two-high mill. Data from these rolling tests are recorded in Table 1. Using small. reductions per pass, it was possible to roll the material to a total of $17 \%$ thickness reduction. Larger reductions per pass resulted in extensive cracking of the homogenized specimens. Samples were cut from the $17 \%$ cold-worked specimen and annealed for one hour at $800^{\circ} \mathrm{C}$, followed by a water quench. As seen in Figure 2, the 


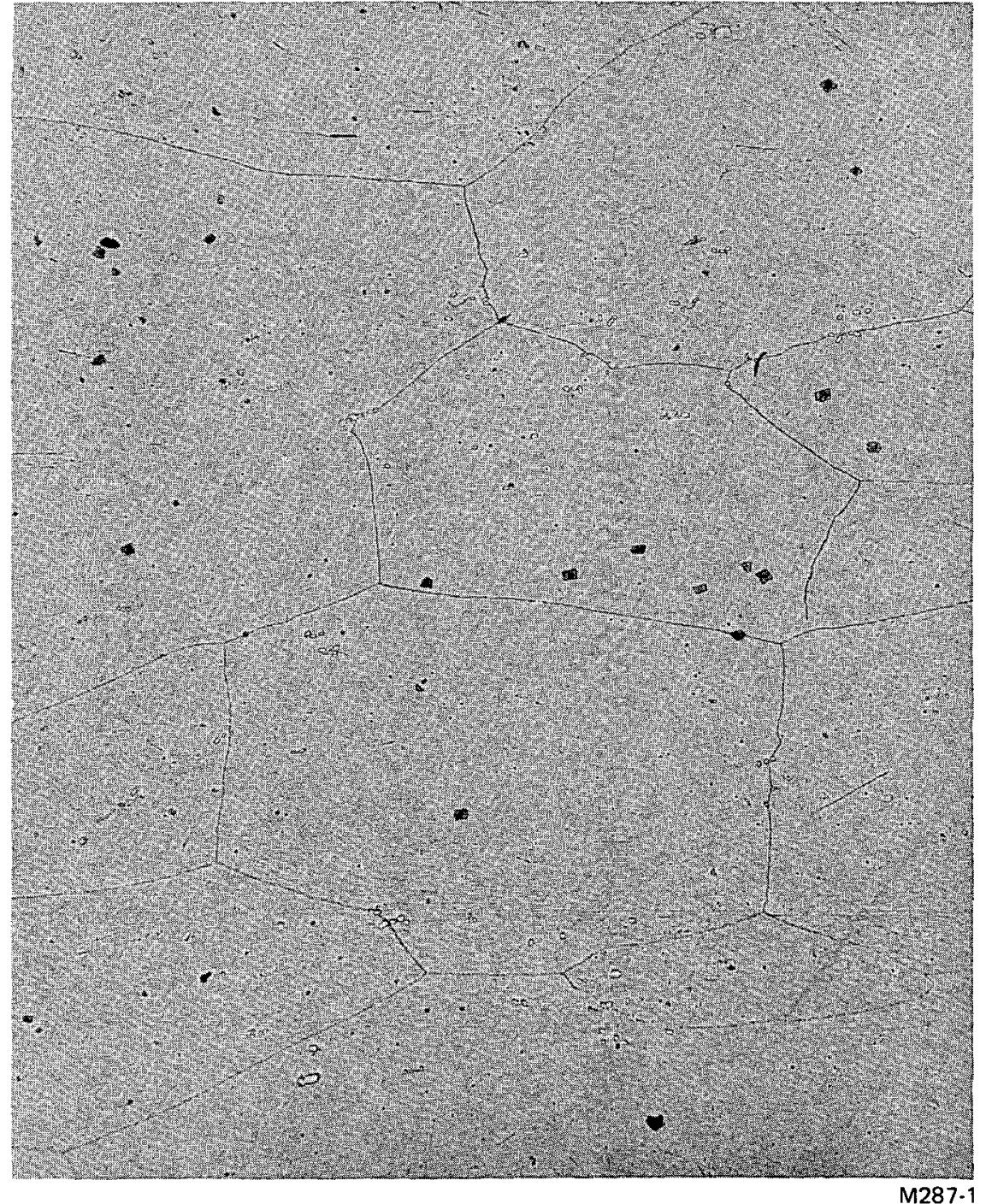

$M 287-1$

Figure 1. MICROSTRUCTURE OF A 12.5-mm SPECIMEN AFTER HOMOGENIZING FOR 12 HOURS AT $1175^{\circ} \mathrm{C}$, VACUUM HEAT TREATING FOR ONE HOUR AT $800^{\circ} \mathrm{C}$ AND WATER QUENCHING. (Bright Field Illumination; 100X)
Table 1

SUMMARY OF THE ROOM-TEMPERATURE ROLLING OF SMALL, HOMOGENIZED SPECIMENS

\begin{tabular}{|c|c|c|c|}
\hline & \multicolumn{3}{|c|}{ Specimen (1) } \\
\hline & $1(2)$ & $2^{(3)}$ & $3(4)$ \\
\hline & Pass 1 & & \\
\hline \multirow[t]{2}{*}{ Reduction (\%) } & 5.8 & 13.0 & 15.3 \\
\hline & Pass 2 & & \\
\hline \multirow[t]{2}{*}{ Reduction (\%) } & 7.2 & 12.3 & \\
\hline & Pass 3 & & \\
\hline Reduction (\%) & 4.9 & & \\
\hline Total & - & - & $\longrightarrow$ \\
\hline Reduction (\%) & 17.0 & 21.0 & 15.3 \\
\hline
\end{tabular}

(1) All specimens had an initial thickness of 14,4 $\mathrm{mm}$ and were homogenized at $1175^{\circ} \mathrm{C}$ for 12
hours, heat treated one hour at $800^{\circ} \mathrm{C}$, and water quenched.

(2) Slightly edge cracking on the last pass.

(3) Cracked on the second pass.

(4) Cracked on the first pass. 


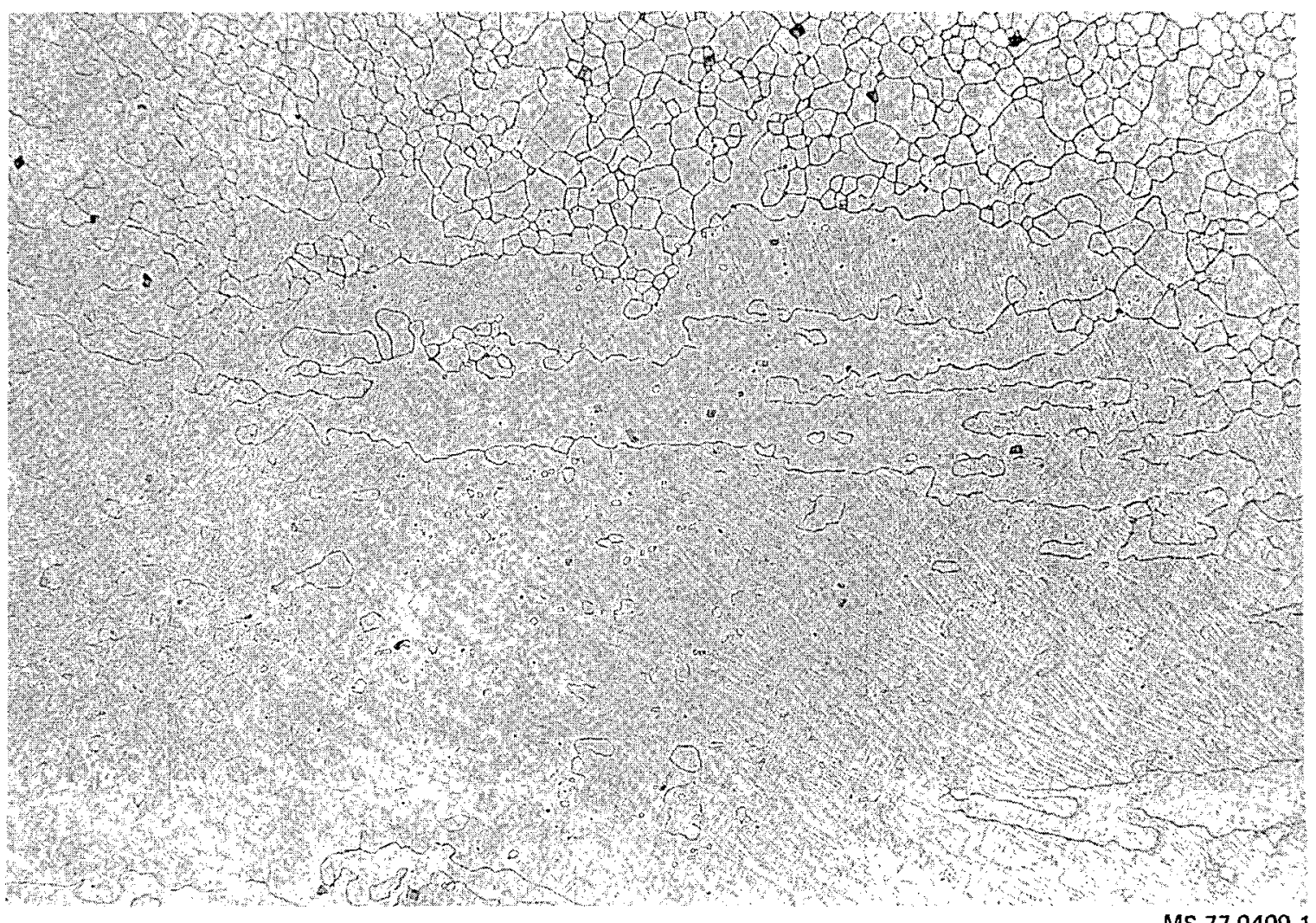

Figure 2. MICROSTRUCTURE OF A URANIUM-6 NIOBIUM SPECIMEN THAT HAS BEEN HOMOGENIZED FOR 12 HOURS AT $1175^{\circ} \mathrm{C}$, HEAT TREATED FOR ONE HOUR AT $800^{\circ} \mathrm{C}$, WATER QUENCHED, COLD WORKED 17 PERCENT, VACUUM HEAT TREATED FOR ONE HOUR AT $800^{\circ} \mathrm{C}$, AND WATER OUENCHED. (Bright Field Illumination; 100X)

material was only partially recrystallized by this cold working-and-annealing treatment. Since the limit of cold working prior to cracking appeared to be approximately $20 \%$ for the homogenized plates, additional plates were rolled at 200 and $700^{\circ} \mathrm{C}$. [It should be mentioned that U-6 Nb plate which has a moderate grain size (ASTM 5-6) can be cold worked to a total of $50 \%$ reduction at room temperature; therefore, the room-temperature ductility of the alloy appeared to be sensitive to grain size at reasonably high strain rates.]

Data for three small specimens which were rolled at $200^{\circ} \mathrm{C}$ from an argon furnace are listed in Table 2. The limit of warm working appears to be between 30 and $46 \%$ reduction, which was a factor of 2 to 3 greater than that achievable at room temperature. Samples of each of the rolled specimens were heat treated at $800^{\circ} \mathrm{C}$ for one hour and water quenched. The microstructures of the specimens can be seen in Figure 3. There was a duplex grain size present in all specimens; however, the material which received only $30 \%$ work contained several large areas which were unrecrystallized. Since the plates which were worked 46 and $48 \%$ were fully recrystallized, a reduction of $40 \%$ (between 30 and $46 \%$ ), followed by heat treating at $800^{\circ} \mathrm{C}$ for one hour, was conjectured to be adequate to recrystallize the homogenized material. It also seemed that a longer heat treatment at $800^{\circ} \mathrm{C}$ would tend to give the final recrystallized plate a more uniform grain size. 
In addition to the warm-rolling treatment, four specimens were also hot rolled from a salt bath at $700^{\circ} \mathrm{C}$. Table 3 reports the results of the rolling experience for these four specimens. Specimen 1 was the first one to be rolled and did not receive a reheat. Because of the time consumed during measurement of thickness during rolling, Specimen 1 cooled to a black heat range and cracked on the last pass. Subsequent plates were given more substantial incremental reductions (up to $46.8 \%)$ in order to keep the billet at least above a dark red heat. There appeared, from these tests, to be no limit to the amount of rolling reduction the homogenized material would accommodate if it were kept above $700^{\circ} \mathrm{C}$. Samples from each of the specimens were heat treated for one hour at $800^{\circ} \mathrm{C}$ and water quenched. The microstructure of each of the specimens is shown in Figure 4. Hot rolling $50 \%$ at $700^{\circ} \mathrm{C}$, followed by $800^{\circ} \mathrm{C}$ for one hour, appeared to be inadequate to fully recrystallize the homogenized specimens. Specimens which received $60 \%$ hot working exhibited a few isolated areas showing incomplete recrystallization. At 69 and $74 \%$ reduction, recrystallization was complete and reasonably uniform.

\section{Large-Scale Study}

Based on the results of the small-scale experiments, a final experiment utilizing production equipment was performed to compare the effects of different forging and homogenization treatments on the chemical homogeneity of rolled plate (Table 4). Plates of the first three processes received a $3.14: 1$ forging reduction, homogenization, and hot rolling to approximately $70 \%$ reduction. The only difference among the three processes was the homogenization treatment. Plates of Process 4 received a $6.25: 1$ forging reduction, prior to homogenization, and a final warm rolling of approximately $40 \%$. Processes 3 and 4 utilized the same homogenization, but included different reductions prior to the homogenization treatment.

Prior experiments on as-cast ingots have shown that the inadvertent homogenization of billets in Processes 3 and 4 should have had essentially no effect on the chemical homogeneity of the rolled plate. ${ }^{1}$ During forging of billets in Processes 3 and 4 , edge cracking occurred which was most likely due to severe forging reductions between reheats. Subsequent billets have been processed in a similar manner by using less severe reductions, and no edge cracking has been observed. ${ }^{2}$ Before homogenizing and rolling, billets of 


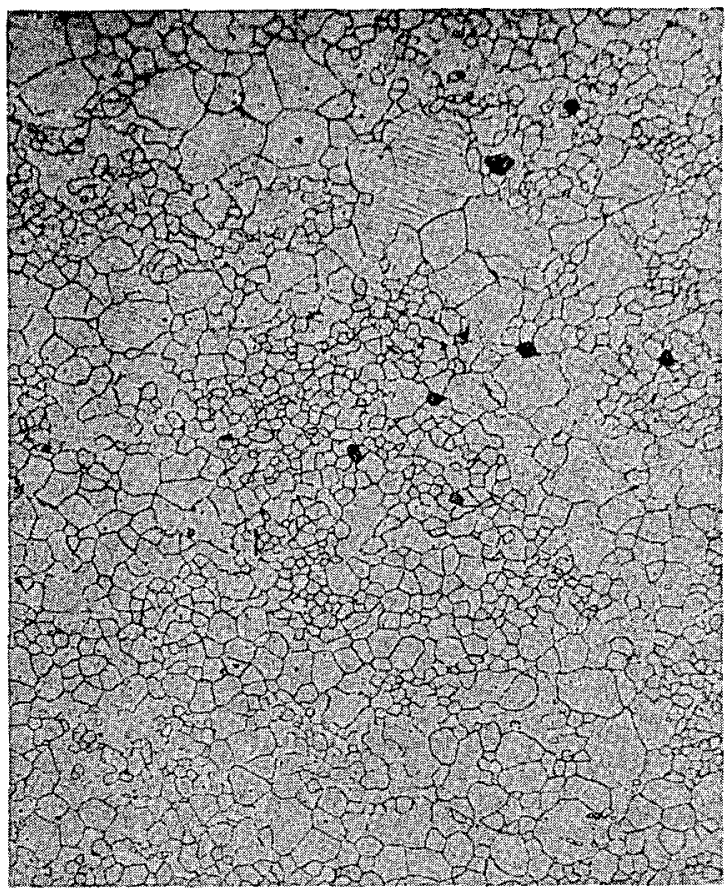

(a) Rolled to $30.0 \%$ Total Reduction.

M290-1

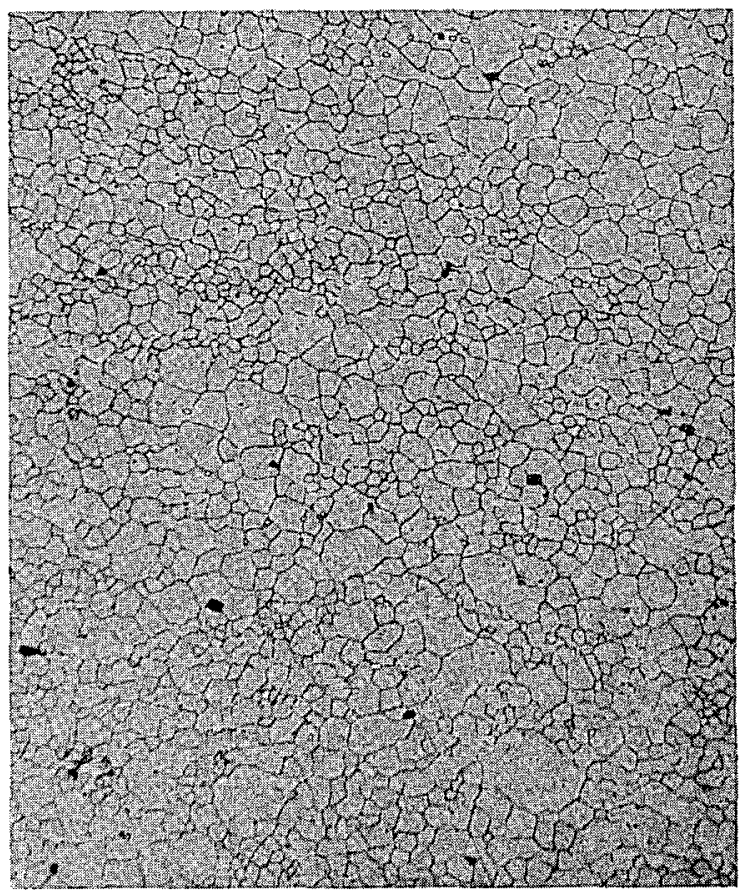

(b) Rolled to $45.7 \%$ Total Reduction.

M290-2

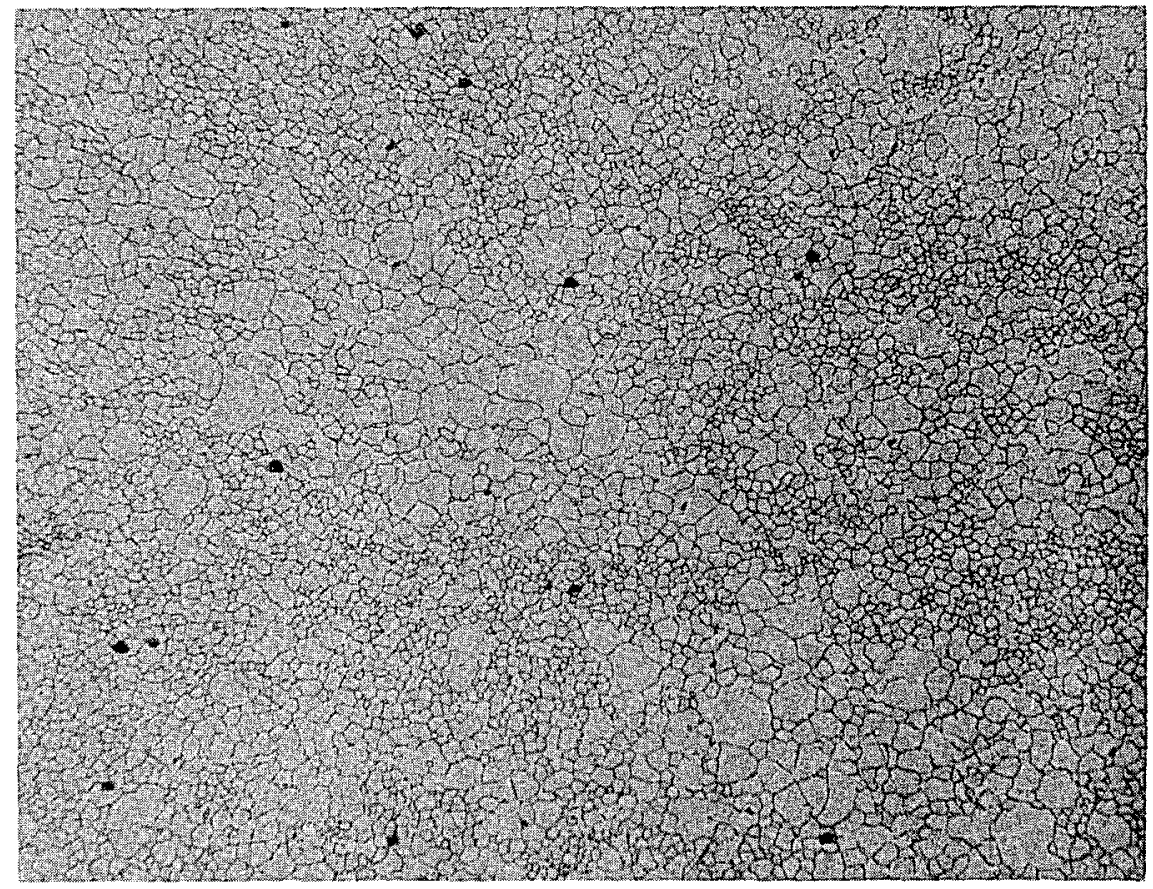

(c) Rolled to $48.0 \%$ Total Reduction.

M290-3

Figure 3. MICROSTRUCTURE OF 14.4-mm SPECIMENS THAT WERE HOMOGENIZED FOR 12 HOURS AT $1175^{\circ} \mathrm{C}$, HEAT TREATED FOR ONE HOUR AT $800^{\circ} \mathrm{C}$ AND WATER QUENCHED, ROLLED TO VARIOUS REDUCTIONS AT $200^{\circ} \mathrm{C}$. THEN GIVEN A FINAL VACUUM HEAT TREATMENT FOR ONE HOUR AT $800^{\circ} \mathrm{C}$ AND WATER QUENCHED. (Bright Field lllumination; 100X) 
Table 3

\begin{tabular}{|c|c|c|c|c|}
\hline \multicolumn{5}{|c|}{$\begin{array}{c}\text { SUMMARY OF } 700^{\circ} \mathrm{C} \text { OF } \\
\text { SMALL, HOMOGENIZED } \\
\text { SPECIMENS }\end{array}$} \\
\hline & \multicolumn{4}{|c|}{ Specimen (1) } \\
\hline & $1(2)$ & 2 & 3 & 4 \\
\hline \multicolumn{5}{|c|}{ Pass 1} \\
\hline Reduction (\%) & 14.8 & 24.0 & 23.5 & 32.2 \\
\hline \multicolumn{5}{|c|}{ Pass 2} \\
\hline \multirow[t]{2}{*}{ Reduction (\%) } & 17.8 & 16.5 & 46.8 & 35.4 \\
\hline & \multicolumn{2}{|c|}{ Pass 3} & & \\
\hline \multirow[t]{2}{*}{ Reduction (\%) } & 13.2 & 20.6 & & 39.7 \\
\hline & \multicolumn{2}{|c|}{ Pass 4} & & \\
\hline Reduction (\%) & 5.8 & & & \\
\hline Total & & & - & 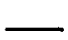 \\
\hline Reduction (\%) & 68.9 & 49.6 & 60.0 & 73.5 \\
\hline
\end{tabular}

(1) All specimens were homogenized at $1175^{\circ} \mathrm{C}$ for 12 hours and heated in the salt bath for one half hour prior to rolling. Starting thickness, $14.6 \mathrm{~mm}$.

(2) Cracked on the last pass.

Table 4

PROCESSING SCHEDULE FOR 12.5-mm PLATE

\begin{tabular}{|c|c|c|c|}
\hline Process $1(1)$ & Process 2 & Process 3 & Process 4 \\
\hline Arc Melt Ingot & Arc Melt Ingot & Arc Melt Ingot & Arc Melt Ingot \\
\hline $\begin{array}{l}\text { Cut Billet } \\
(140 \mathrm{~mm} \dot{\phi} \times 140 \mathrm{~mm})\end{array}$ & $\begin{array}{l}\text { Cut Billet } \\
(140 \mathrm{~mm} \phi \times 140 \mathrm{~mm})\end{array}$ & $\begin{array}{l}\text { Cut Billet }{ }^{(2)} \\
\quad(140 \mathrm{~mm} \phi \times 140 \mathrm{~mm})\end{array}$ & $\begin{array}{l}\text { Cut Billet }{ }^{(2)} \\
\qquad(140 \mathrm{~mm} \phi \times 140 \mathrm{~mm}\end{array}$ \\
\hline $\begin{array}{l}\text { Forge to } 44.5 \mathrm{~mm} \\
\text { at } 850^{\circ} \mathrm{C}\end{array}$ & $\begin{array}{l}\text { Forge to } 44.5 \mathrm{~mm} \\
\text { at } 850^{\circ} \mathrm{C}\end{array}$ & $\begin{array}{l}\text { Forge to } 44.5 \mathrm{~mm} \\
\text { at } 850^{\circ} \mathrm{C}\end{array}$ & $\begin{array}{l}\text { Forge to } 22.4 \mathrm{~mm} \\
\text { at } 850^{\circ} \mathrm{C}\end{array}$ \\
\hline $\begin{array}{l}\text { Homogenize for } 4 \text { hrs } \\
\text { at } 1000^{\circ} \mathrm{C}\end{array}$ & $\begin{array}{l}\text { Homogenize for } 10 \mathrm{hrs} \\
\text { at } 1050^{\circ} \mathrm{C}\end{array}$ & $\begin{array}{l}\text { Homogenize for } 18 \mathrm{hrs} \\
\text { at } 1175^{\circ} \mathrm{C}\end{array}$ & $\begin{array}{l}\text { Homogenize for } 18 \mathrm{hrs} \\
\text { at } 1175^{\circ} \mathrm{C}\end{array}$ \\
\hline $\begin{array}{l}\text { Round Roll at } \\
850^{\circ} \mathrm{C} \text { to } 12.5 \mathrm{~mm}^{(3)}\end{array}$ & $\begin{array}{l}\text { Round Roll at } \\
850^{\circ} \mathrm{C} \text { to } 12.5 \mathrm{~mm}\end{array}$ & $\begin{array}{l}\text { Round Roll at } \\
850^{\circ} \mathrm{C} \text { to } 12.5 \mathrm{~mm}\end{array}$ & $\begin{array}{l}\text { Round Roll at } \\
200^{\circ} \mathrm{C} \text { to } 12.5 \mathrm{~mm}\end{array}$ \\
\hline
\end{tabular}

(1) Two plates were produced by each process.

(2) Homogenization of 10 hours at $1050^{\circ} \mathrm{C}$ inadvertently given to this billet.

(3) All plates were heat treated (immediately after rolling) for one hour at $800^{\circ} \mathrm{C}$ in an argon furnace and water quenched. Plates were subsequently flattened by forging between two platens and given a final vacuum heat treatment for one hour at $800^{\circ} \mathrm{C}$, followed by a water quench. 


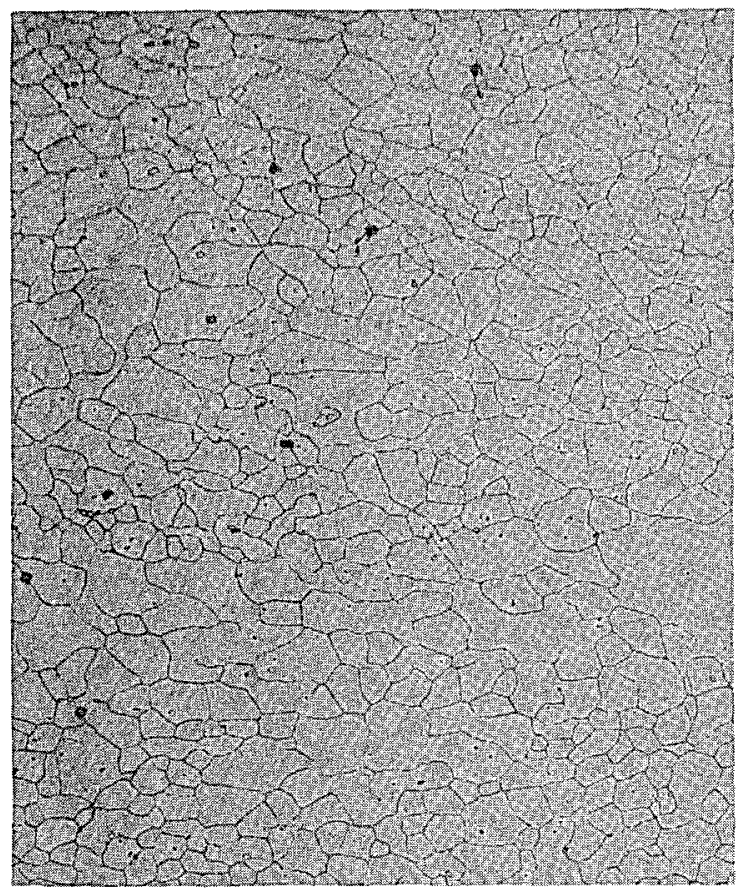

(a) Hot Rolled $50 \%$.

M290-4

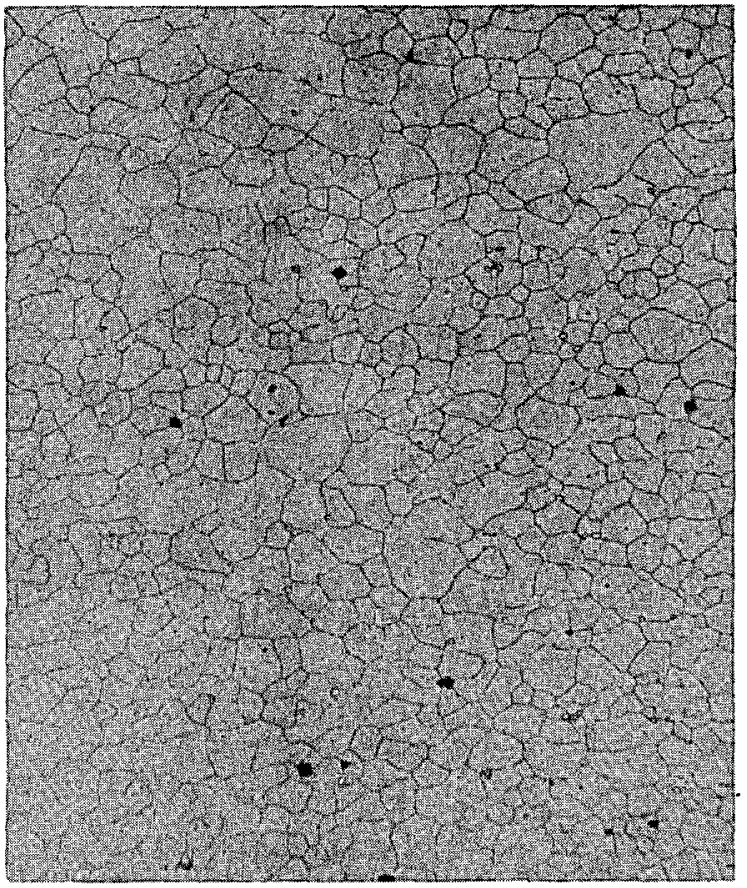

(b) Hot Rolled $60 \%$.

M290-5

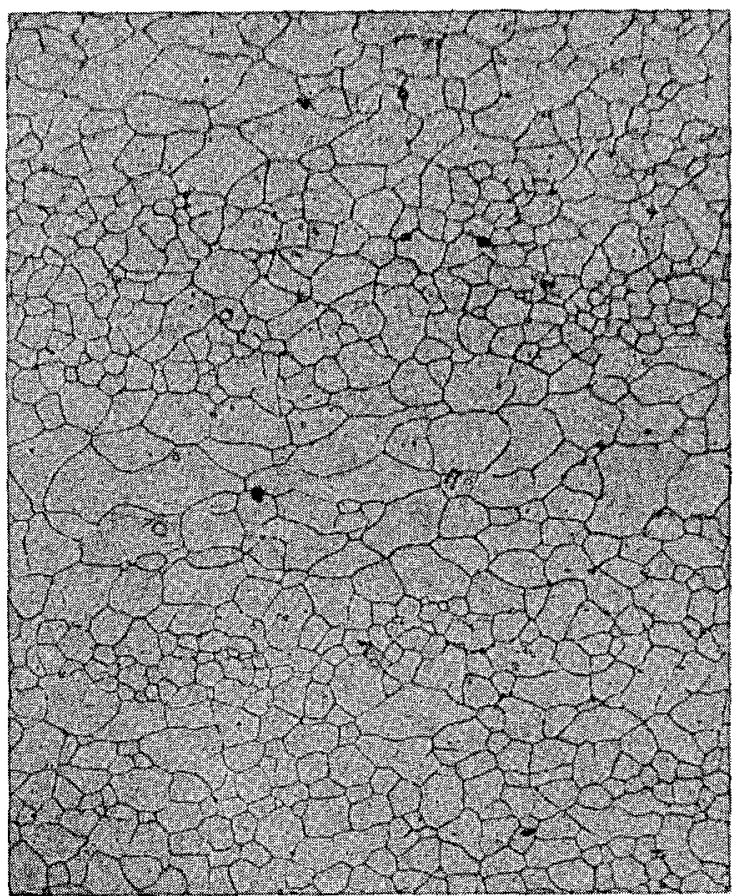

(c) Hot Rolled $69 \%$.

M290-6

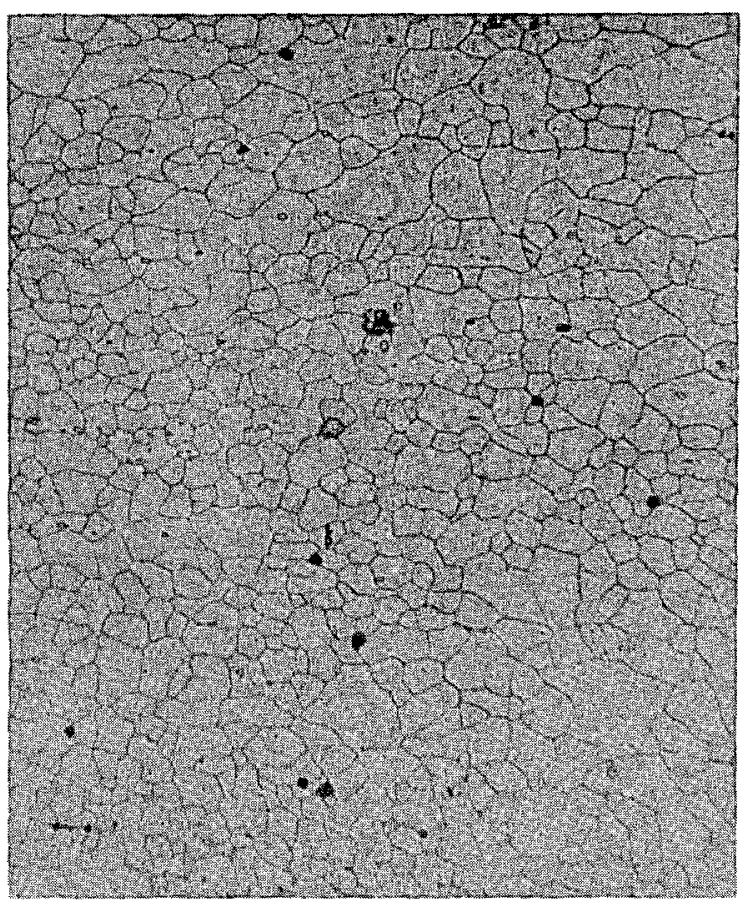

(d) Hot Rolled $74 \%$.

M290-7

Figure 4. MICROSTRUCTURE OF 14.4-mm SPECIMENS THAT WERE HOMOGENIZED FOR 12 HOURS AT $1175^{\circ} \mathrm{C}$, ROLLED AT $700^{\circ} \mathrm{C}$ TO VARIOUS REDUCTIONS, HEAT TREATED FOR ONE HOUR AT $800^{\circ} \mathrm{C}$, AND WATER QUENCHED. (Bright Field Illumination; 100X) 
Processes 3 and 4 were machined to remove any edge cracking. Plates in Processes 1 through 3 were hot rolled according to the schedule shown in the left-hand column of Table 5, while plates of Process 4 were warm rolled according to the schedule given in the right-hand column. Plates in Processes 1 and 2 were rolled successfully. However, because of the small size and difficulty in handling, the first plate of Process 3 cooled to too low a temperature and cracked. The second plate of Process 3 was reheated before Step 5 and rolled successfully. Both plates in Process 4 cracked on the last pass due to excessive working. However, an average total reduction of $36 \%$ was achieved prior to the last pass. Thus, it would be possible to design a warm-rolling schedule to produce a total reduction of $36 \%$ in sound plate. Such a reduction would produce full recrystallization in plate processed from homogenized billets.

Optical microstructures taken from the center of representative plates of all four processes are shown in Figure 5. Plate produced by Process 1 had the largest grain size (ASTM 4 - 5), whereas plates from Process 4 had the smallest grain size (ASTM $8-8 \frac{1}{2}$ ). Plates from Processes 2 and 3 had an intermediate grain size (ASTM 61/2- 71/2).

Table 5 ROLLING SCHEDULE FOR FULL-SIZE PLATE

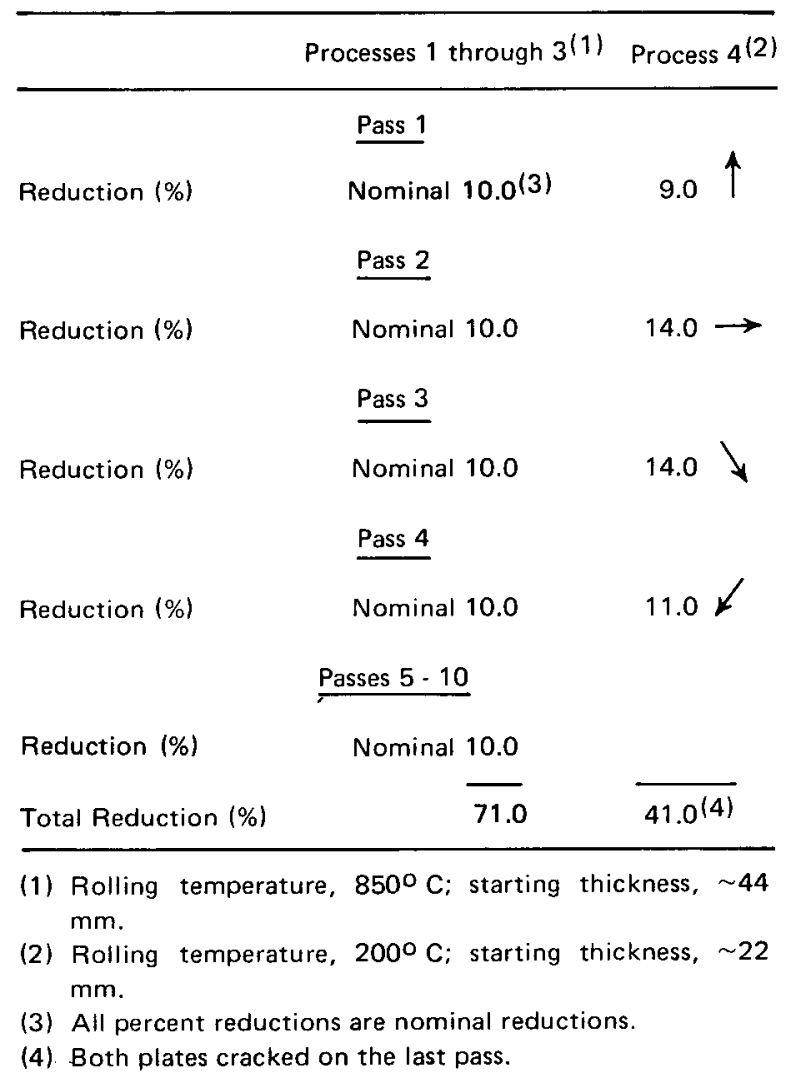

In a prior study, ${ }^{3}$ it was discovered that chemical inhomogeneities in plates of U-6 Nb could be accentuated by heat treating for one half hour at $600^{\circ} \mathrm{C}$ and water quenching. Because the rate of decomposition of the gamma phase was very sensitive to niobium concentration, pearlite formed first in the niobium-rich areas, thus outlining regions of high niobium content. Specimens from the center region of plates produced in the four processes were heat treated isothermally for one half hour at $600^{\circ} \mathrm{C}$ in vacuum and water quenched. Polarized-light microstructures of these plates are included (Figure 6). As a more complete check on the chemical homogeneity of the plates, microprobe traces for niobium were made on the specimens of Figure 4. These traces (shown in Figures 7 and 8) were made at increments of 10 and $50 \mu \mathrm{m}$ over distances of 1500 and $7500 \mu \mathrm{m}$, respectively.

Theoretical calculations of niobium-concentration profiles for forged, homogenized, and rolled plate were performed by using the following equation: 1 


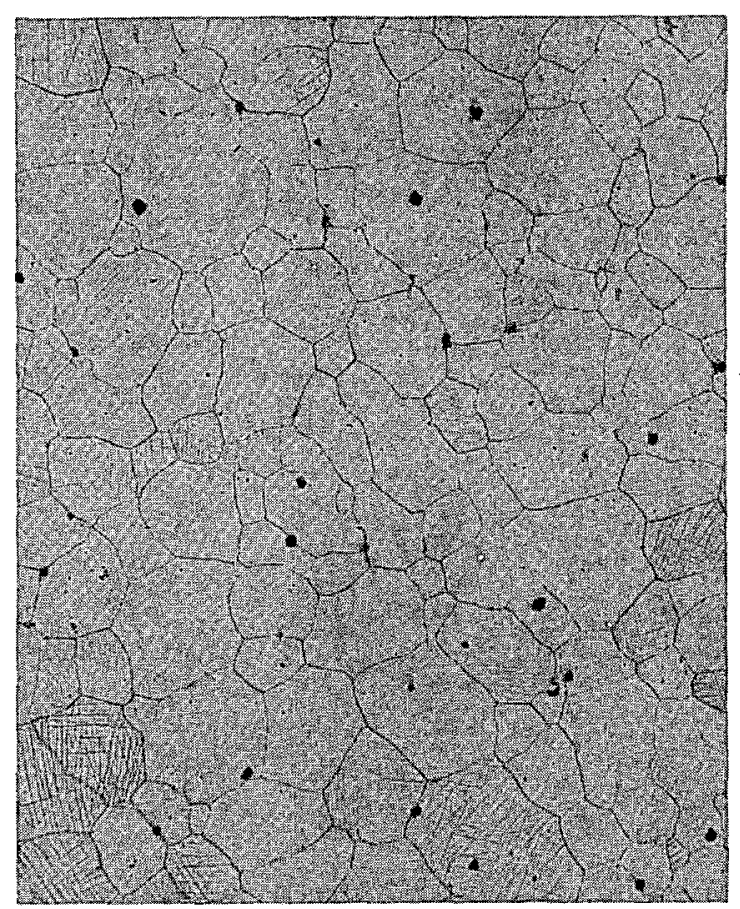

(a) Process 1. (ASTM 4 - 5)

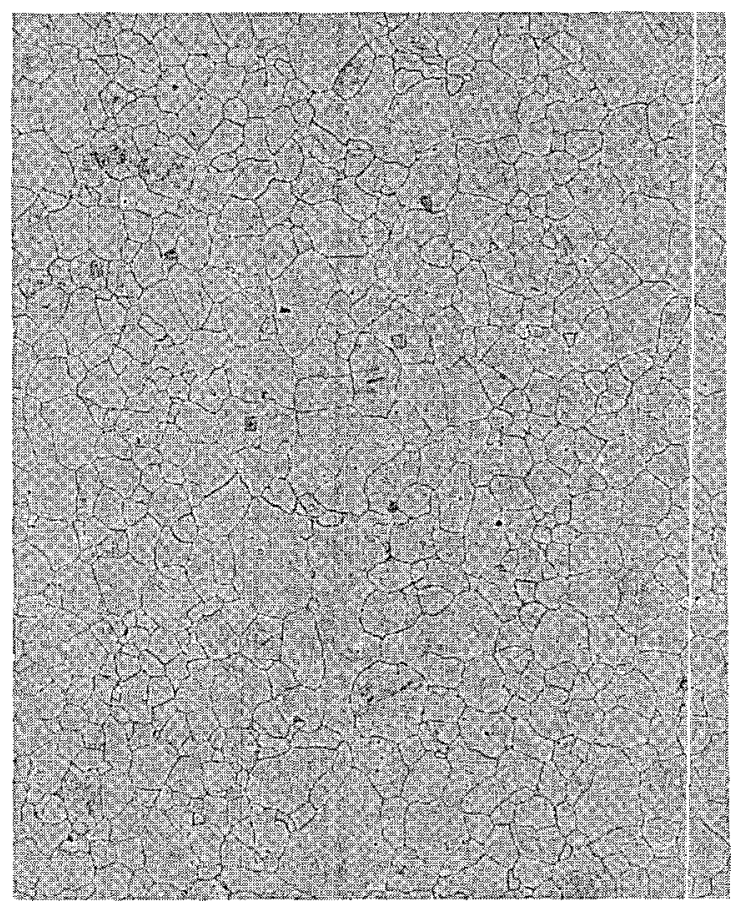

(b) Process 2. (ASTM $7-71 / 2$ )

N1374
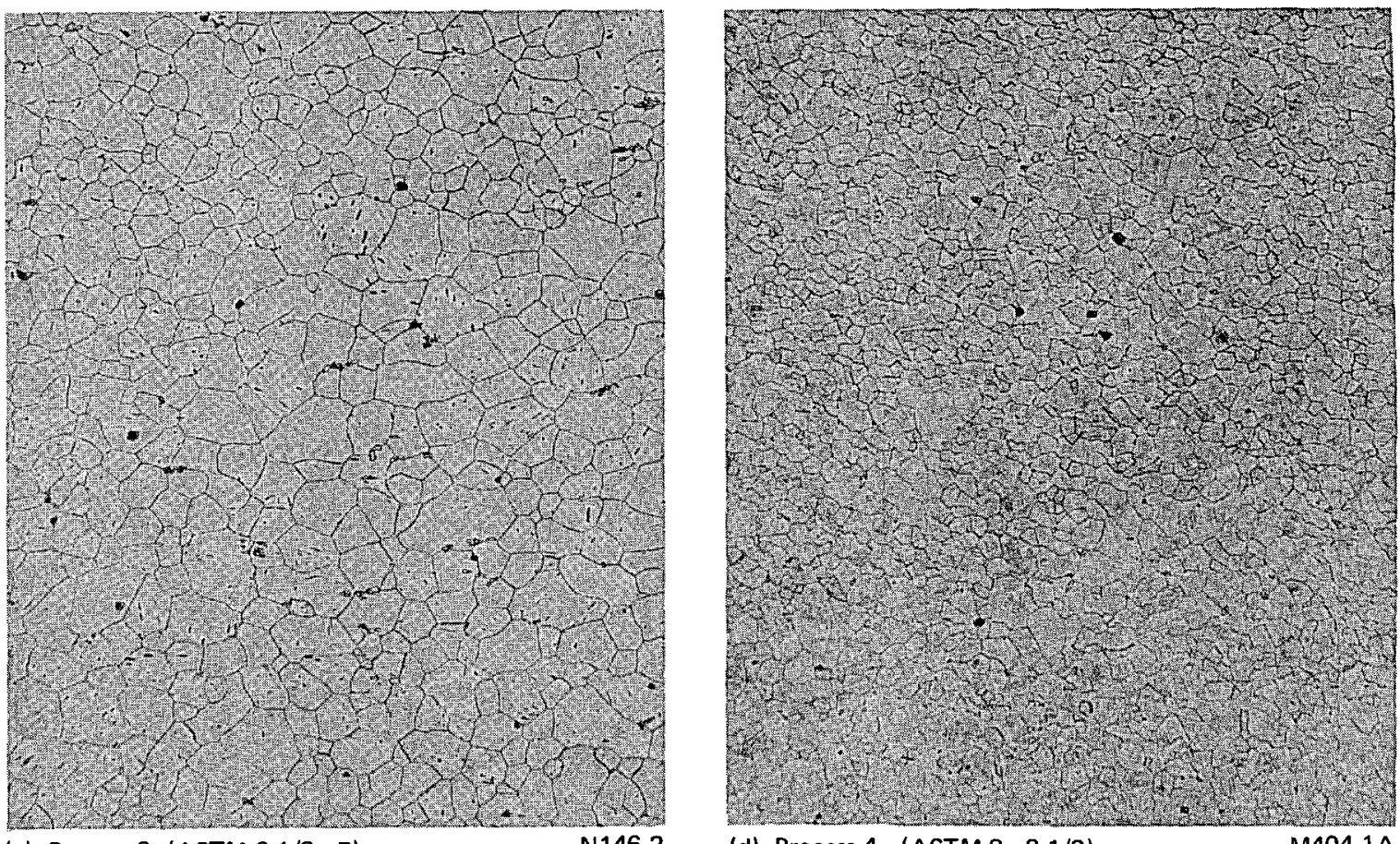

(c) Process 3. (ASTM 6 1/2 - 7)

N146-2

(d) Process 4. (ASTM $8-8$ 1/2)

M404-1A

Figure 5. OPTICAL MICROSTRUCTURE OF PLATES THAT WERE PRODUCED BY THE FOUR PROCESSES. (Bright Field Illumination; 100X) 


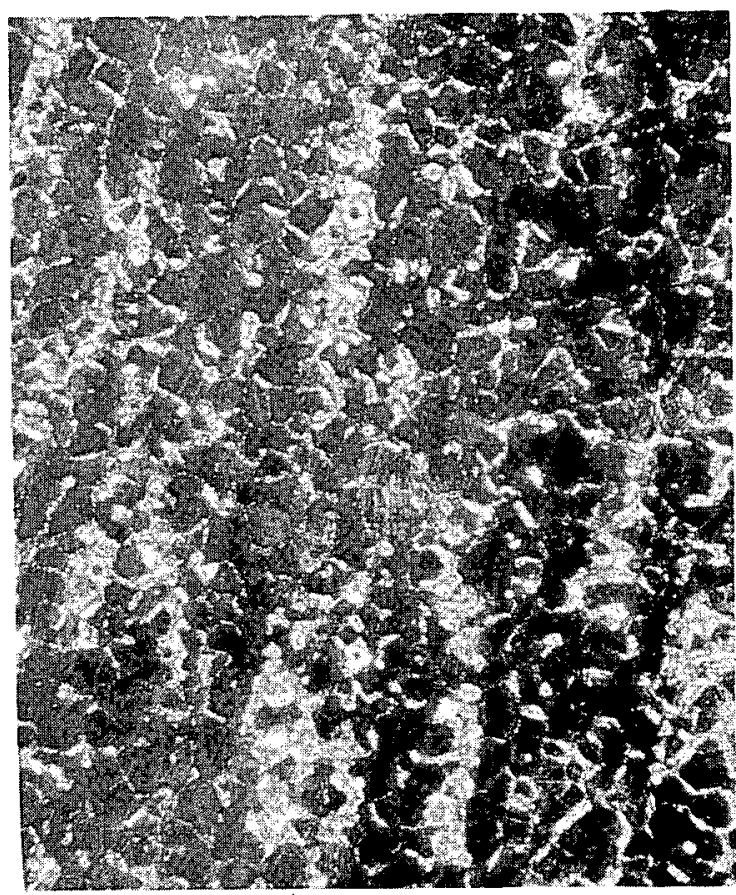

(a) Process 1.

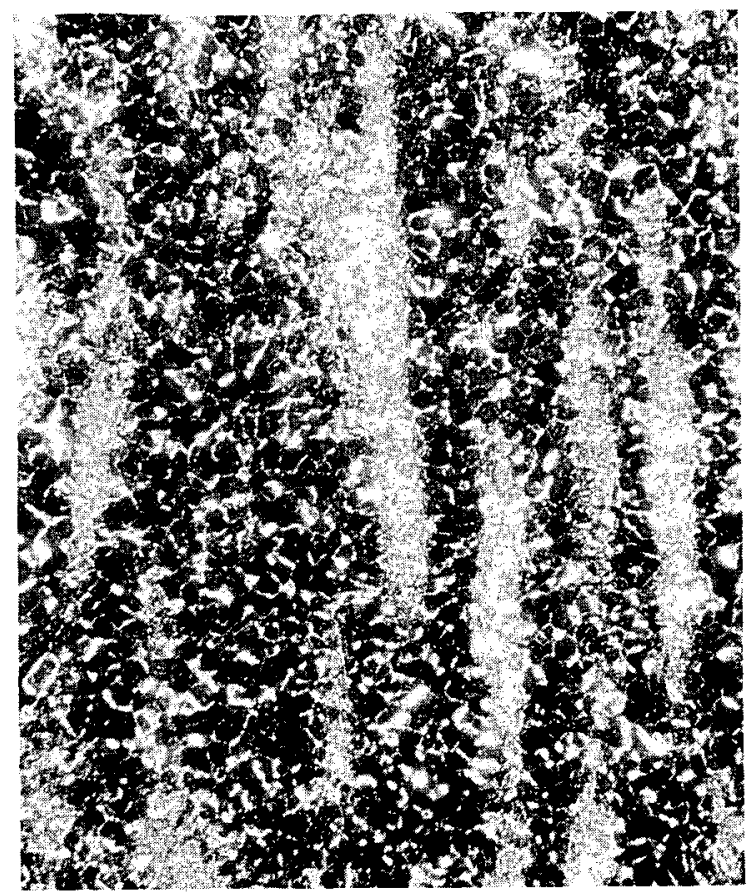

(b) Process 2.

N203-1

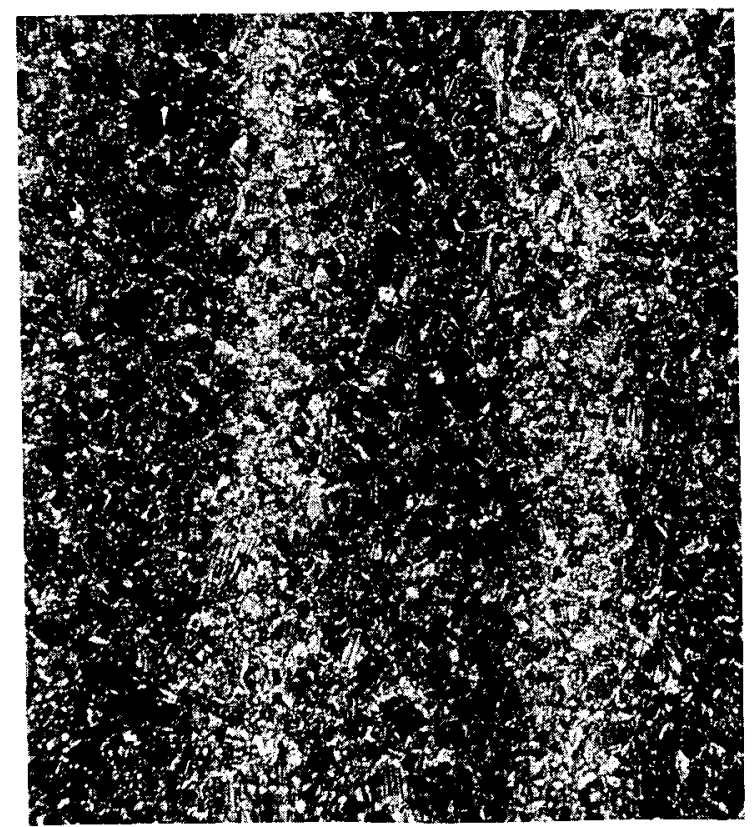

(c) Process 3.

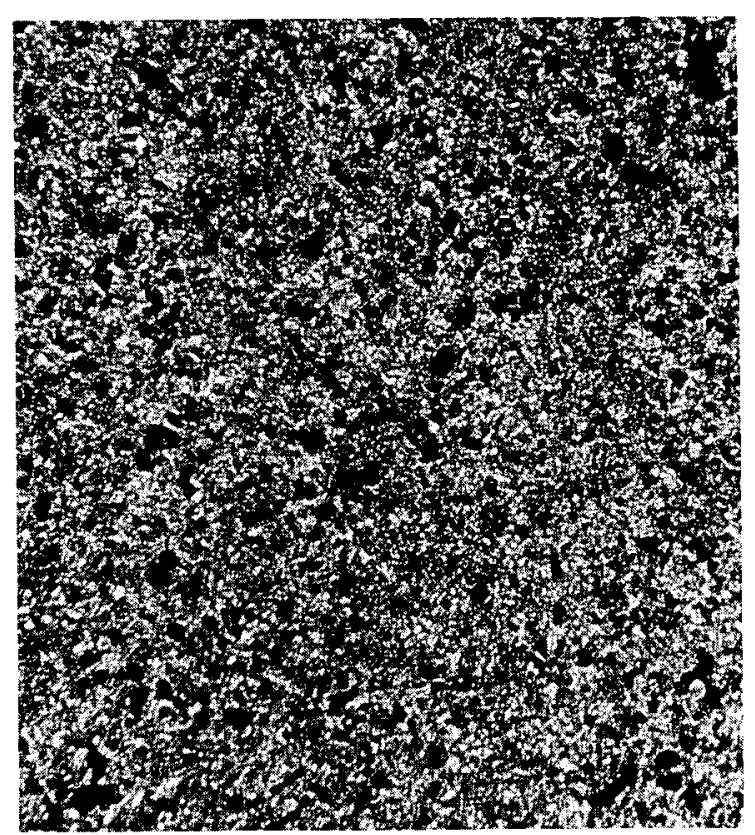

(d) Process 4.

M404-3A

Figure 6. MICROSTRUCTURE OF THE CENTER PORTION OF PLATES THAT WERE FABRICATED BY THE FOUR PROCESSES, ISOTHERMALLY HEAT TREATED AT $600^{\circ} \mathrm{C}$ FOR ONE HALF HOUR, AND WATER QUENCHED. (Polarized Light; 50X) 
Experimental Traces
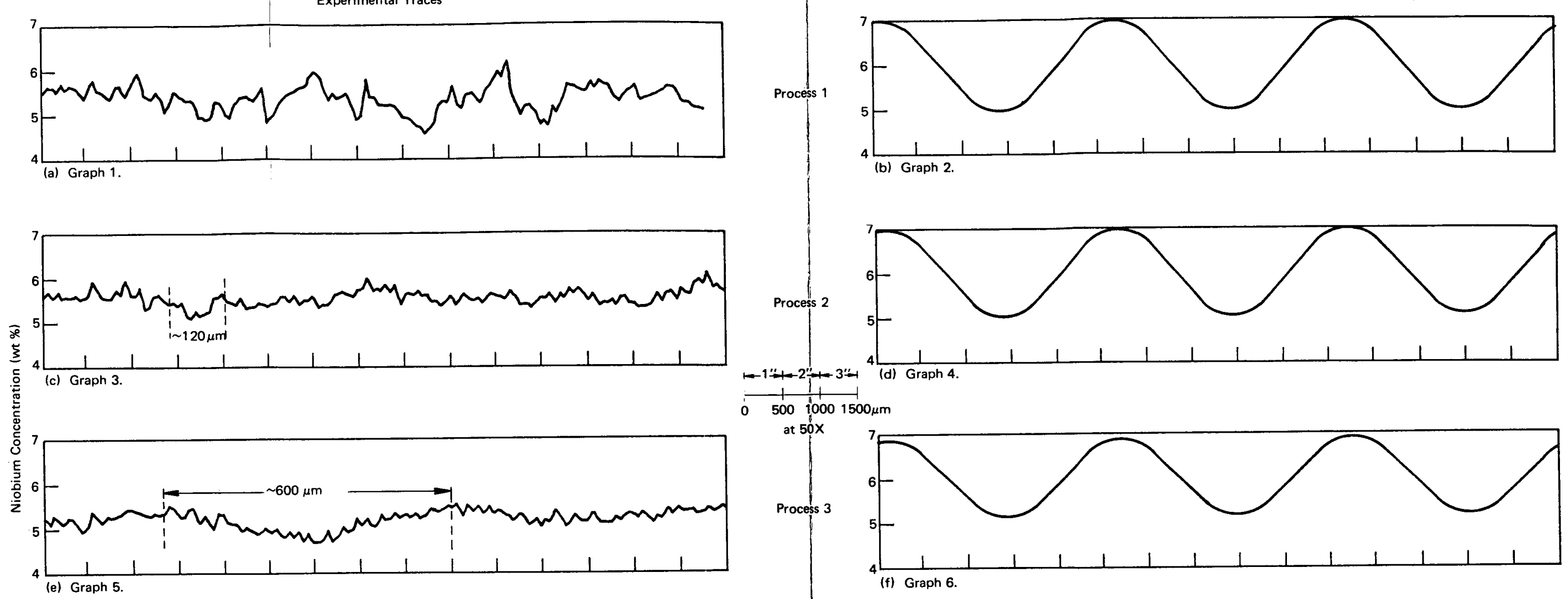
(1)

50010001500
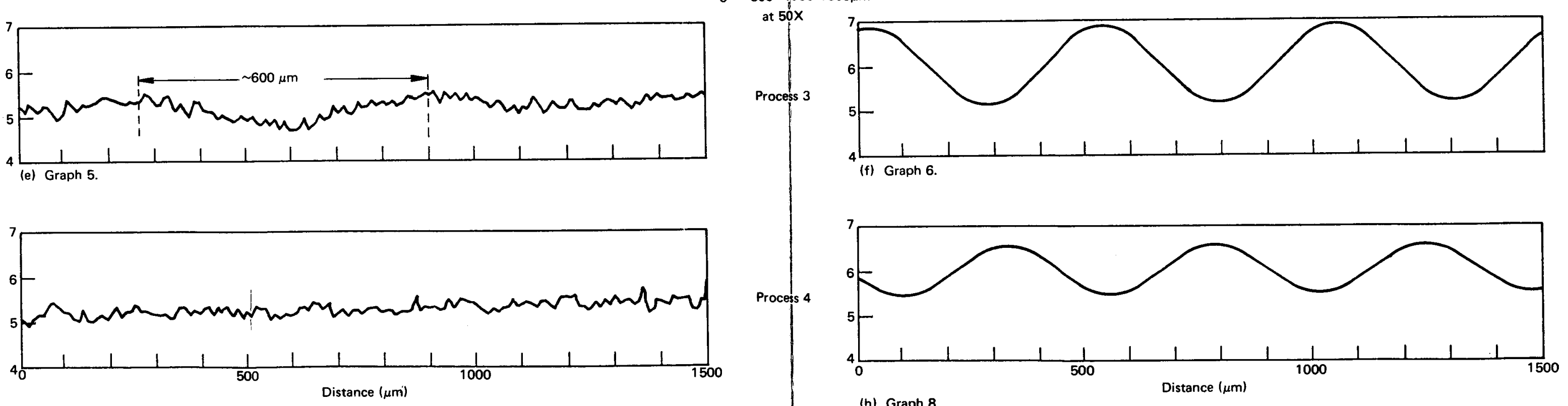

(h) Graph 8 .

Figure 7. MICROPROBE TRACES AND THEORETICAL CALCULATIONS OF THE NIOBIUM DISTRIBUTION THROUGH THE THICKNESS OF 12.5-mm URANIUMNIOBIUM PLATE. (Process 1-3.14:1 Forging Reduction, 4-Hour Homogenization at 1000看; Process 2-3.14:1 Forging Reduction, 10-Hour Homogenization at $1050^{\circ} \mathrm{C}$

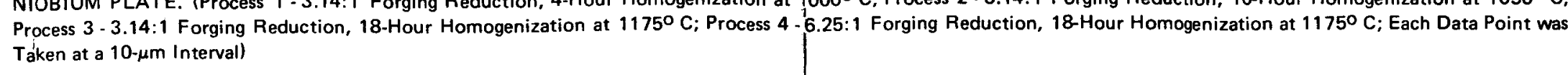


Experimental Traces

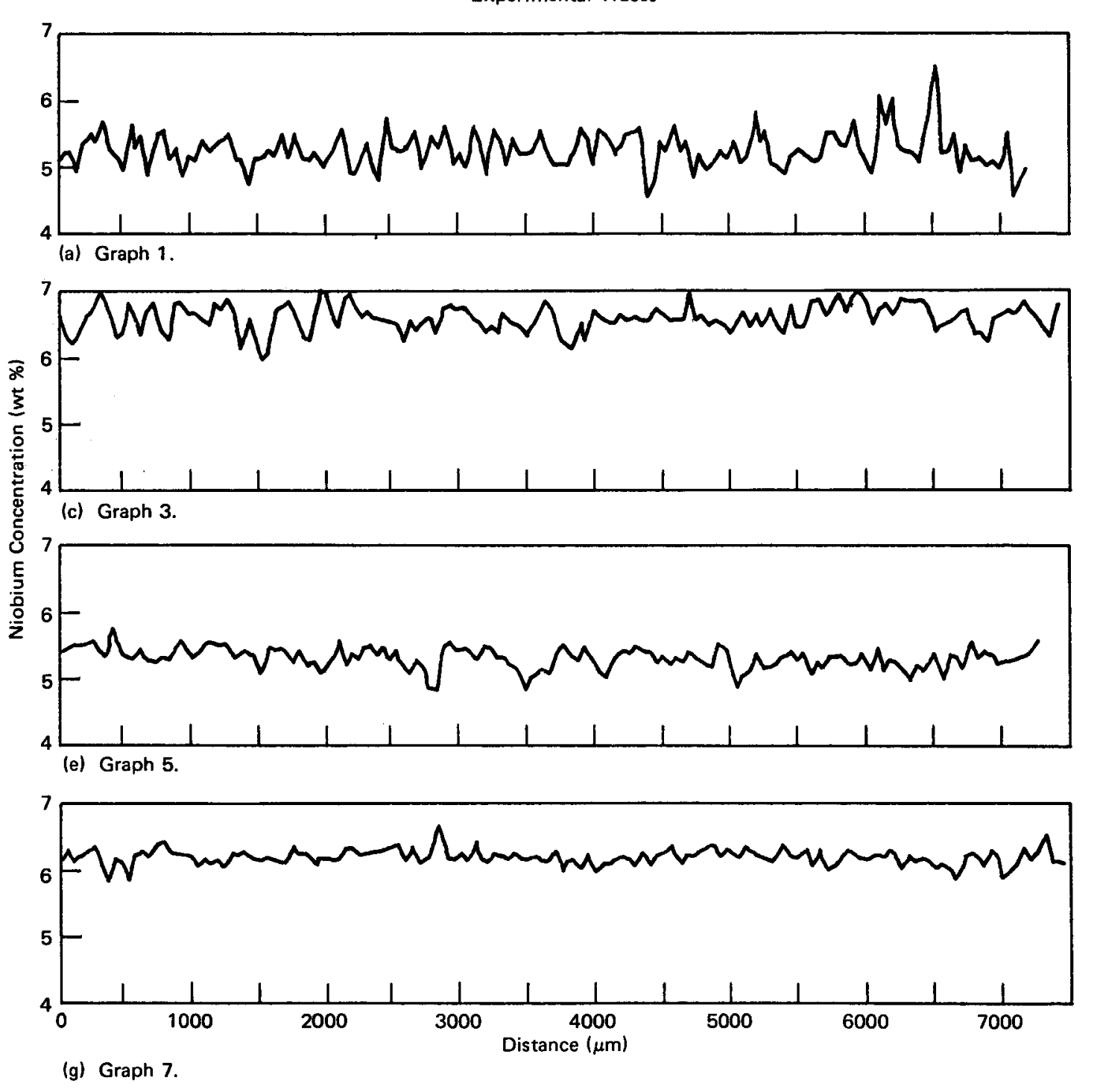

Theoretical Calculations

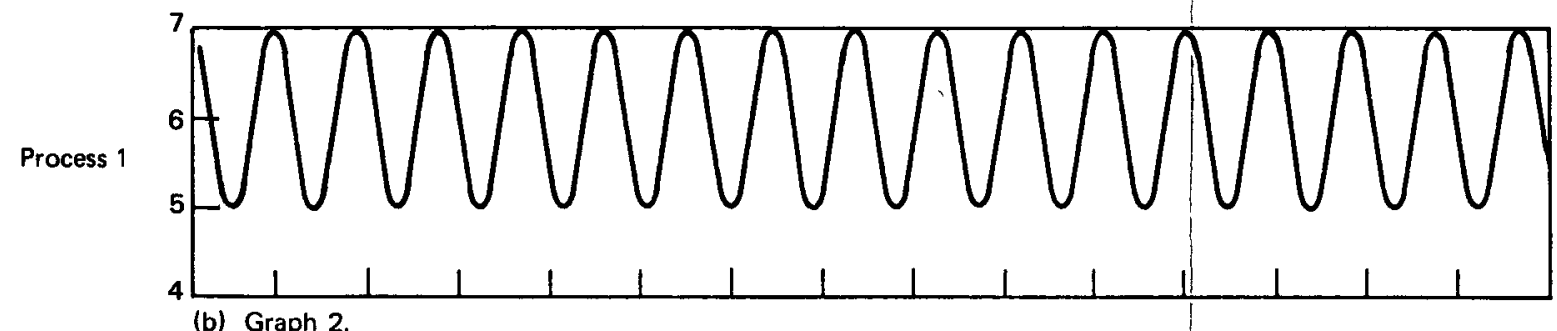

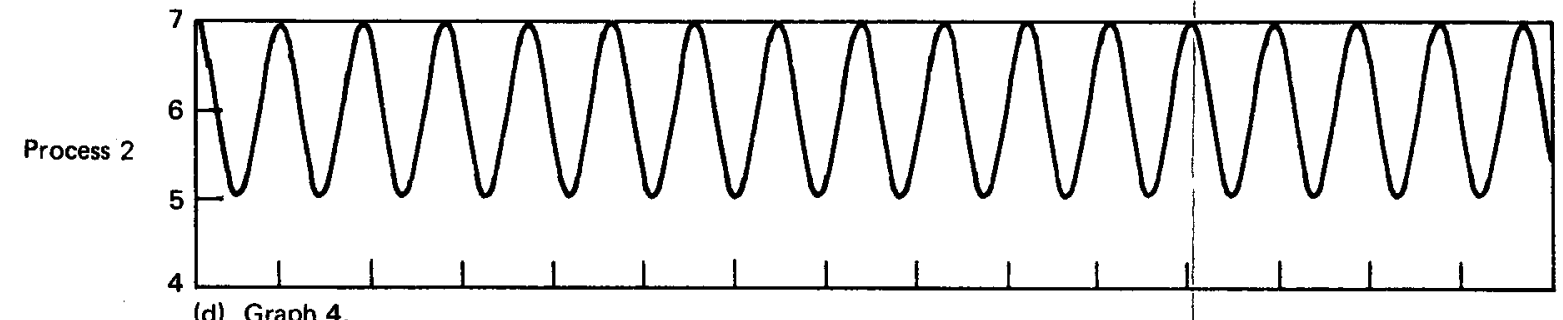

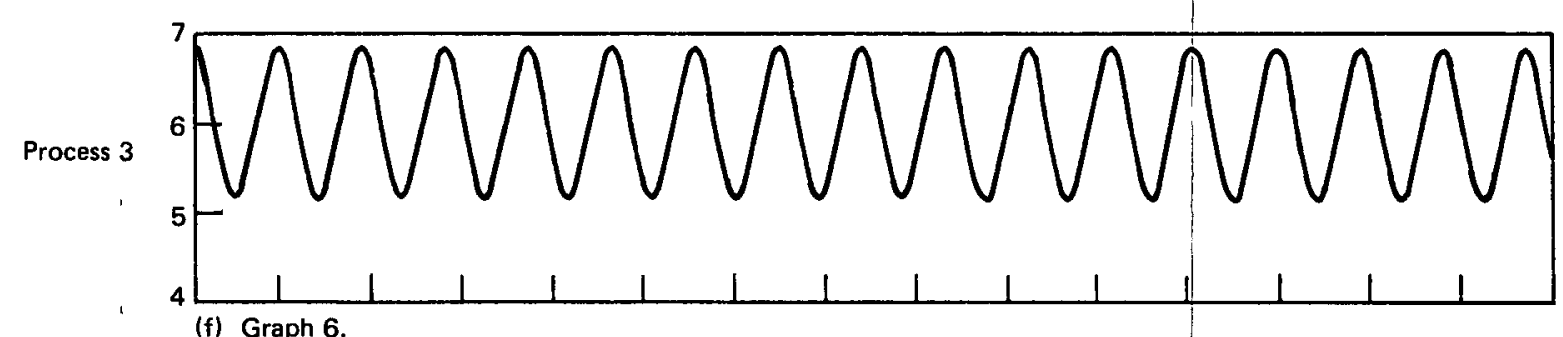

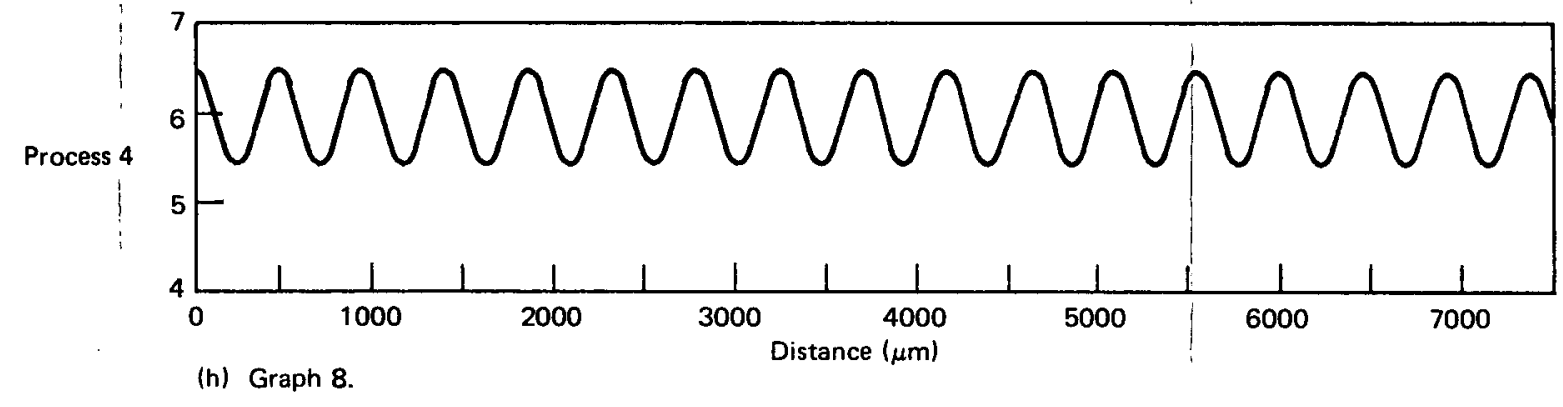

Figure 8. MICROPROBE TRACES AND THEORETICAL CALCULATIONS OF THE NIOBIUM DISTRIBUTION THROUGH THE THICKNESS OF A 12.5-mm URANIUM-6

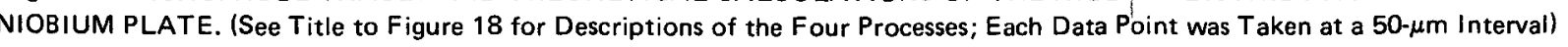


$C(x, t)=C_{o}+A_{c}\left[\cos \left(\frac{\pi x}{W_{c}}\right)\right]\left[\exp \left(\frac{-\pi^{2} D t}{\left(W_{c}\right)^{2} 10^{-8}}\right)\right]+A_{b}\left[\cos \left(\frac{\pi x}{W_{b}}\right)\right]\left[\exp \left(\frac{-\pi^{2} D t}{\left(W_{b}\right)^{2} 10^{-8}}\right)\right]$.

This equation gives the niobium concentration at any distance, $x$, after a given diffusion time, $t$. The diffusion coefficient is given as $D=1.4 \times 10^{-4} \exp (-36,200 / R T) \mathrm{cm}^{2} / \mathrm{sec}^{4}$ In Equation $1, A_{C}$ is the amplitude of the interdendritic (short-wavelength) segregation (in wt $\%$ ), which has been measured on as-cast material to be $2.5 \mathrm{wt} \% ; A_{b}$ is the amplitude of banding (long-wavelength) segregation (in wt \%), which has also been measured on as-cast material to be $1.0 \% ; W_{C}$ is half the interdendritic spacing (in $\mu \mathrm{m}$ ), which has been measured on as-cast material to be $\sim 75 \mu \mathrm{m}$; $W_{\mathrm{b}}$ is half the banding spacing (in $\mu \mathrm{m}$ ), measured to be $\sim 2500 \mu \mathrm{m}$ for as-cast material, and $C_{0}$ was taken to be 6.0 , which is the nominal composition of the alloy.

Concentration profiles for 12.5-mm-thick plate were produced by assuming that interdendritic spacing, $W_{C}$, and interband spacing, $W_{b}$, were reduced from those of the cast ingot by the appropriate forging ratios. For instance, if the billet was reduced from 137.7 $\mathrm{mm}$ in height to $44.5 \mathrm{~mm}$ (a ratio of $3.14: 1$ ) before homogenizing, $W_{c}$ and $W_{b}$ were reduced by the same ratio before the effects of homogenizing were calculated. It was also assumed that no further homogenization occurred during rolling and final heat treatment. The final profiles were plotted on a scale which accounted for a total reduction from ingot to plate of $11: 1$.

\section{DISCUSSION OF RESULTS}

\section{Observed Microstructure}

The sensitivity of large-grained (ASTM 00) U-6 Nb to cracking during cold rolling was somewhat surprising and required an examination of alternate methods of grain refinement. A review of available literature on the uranium-rich, uranium-niobium alloys indicates that no systematic study of the effects of either strain rate or grain size on the mechanical properties of the U-6 $\mathrm{Nb}$ alloy has been performed. Such a study should be undertaken to more clearly define the working range of homogenized ingots and billets.

A wide variation in grain size was noted in plates produced from all four processes (Figure 5). Warm rolling would normally be expected to produce a finer-grained material; and, in this instance, plate of Process 4 had a very fine grain size (ASTM $8-8 \frac{1}{2}$ ). However, the variation of grain size in the plates of Processes 1 through 3 was unexpected. It would be anticipated that the extensive homogenization given the billets of Process 3 would result in the largest-grained material. However, Process 1, which included the lowest-temperature homogenization treatment, yielded the largest grain size. There appears to be no suitable explanation for this effect.

Clearly, the most homogeneous plates produced were those from Process 4. Microprobe traces of these plates at both 10 and $50-\mu \mathrm{m}$ increments show the most consistent uniformity 
in niobium content (Figures 7 and 8 ). The microstructure of this plate (Figure 6, View d) was also the most uniform. Of the four processes, Process 1 , which represents the current Y-12 Plant standard practice, produced the poorest plates from the standpoint of niobium uniformity. Microprobe traces of these plates showed a variation in niobium content of from 4.6 to $6.2 \%$. Microprobe traces of plates from Processes 2, and 3 appeared to be very similar. A closer examination of these traces revealed that the plate of Process 2 contained more short-range homogeneities (Figure 7, Graph c), while plate from Process 3 contained longer-range inhomogeneities, Graph e. The microstructures of these two plates also exhibited similar differences. Plate 2 showed many shorter, more closely spaced bright areas, which correspond to regions of higher niobium content. On the other hand, Plate 3 showed very regularly spaced regions of high niobium content (brighter bands) which extend for long distances parallel to the plane of the plate. The measured wavelength of banding segregation in Graph e (Figure 7), $600 \mu \mathrm{m}$, corresponds to a banding spacing of $6600 \mu \mathrm{m}$ in the as-cast ingot (using an 11:1 reduction from ingot to plate). Considering the variation which exists in band spacing, the $6600 \mu \mathrm{m}$ is in reasonable agreement with the $5000 \mu \mathrm{m}$ estimated in previous studies. ${ }^{1}$ A comparison of Graphs c, e, and $g$ of Figure 7 shows that increased forging reduction, prior to homogenization (Graphs e and $\mathrm{g}$ ), was more important than higher temperatures and longer soak times during homogenization (Graphs $\mathrm{c}$ and e).

\section{Comparison to the Model}

Predictions of plate inhomogeneities from the model used were quite inaccurate. For instance, the maximum variation in niobium content calculated for Graph $f$ (Figure 7) was \pm 0.8 wt $\%$, while the measured variation was $\pm 0.3 \mathrm{wt} \%$. In examining the model, it appeared reasonable to assume a reduction in interband spacing equivalent to the forging reduction. Measurements such as those of Graph e substantiated the assumption. However, it seemed that the activation energy for the diffusion of niobium in uranium might be lower than that of Peterson and Ogilvie, ${ }^{4}$ used in the model. It was noted by Peterson and Ogilvie that the activation energy was perhaps a function of composition. However, they did not determine the compositional dependence and it, therefore, was not included in the model. Figure 9 illustrates the effect of lowering the activation energy of $32,600 \mathrm{cal} / \mathrm{mole}$ by $10 \%$ $(29,340 \mathrm{cal} / \mathrm{mole})$ and $15 \%(27,710 \mathrm{cal} / \mathrm{mole})$. The conditions of forging and homogenization
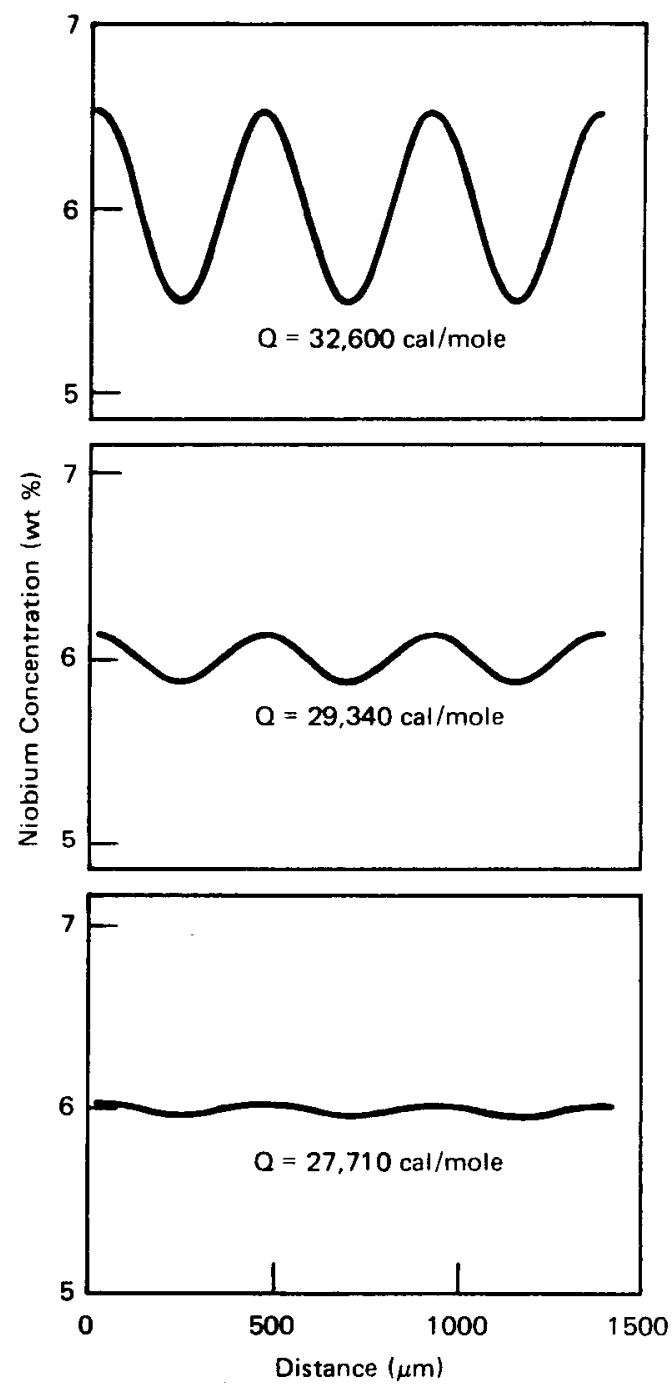

Figure 9. EFFECT OF LOWERING THE DIFFUSION ACTIVATION ENERGY FOR NIOBIUM IN URANIUM (BY 10 AND 15\%) ON THE COMPUTED CONCENTRATION PROFILES. (Compared these Curves with Graphs $g$ and $h$ of Figure 8 ) 
for Figure 9 are identical to those of Graphs $g$ and $h$ of Figure 8; ie, 6.25:1 forging reduction and 18 hours at a $1175^{\circ} \mathrm{C}$ homogenization treatment. Note that the experimental data of Graph $g$ are in very good agreement with the activation energy between 27,710 and $29,340 \mathrm{cal} / \mathrm{mole}$. These results would thus suggest that the activation energy for niobium diffusion in the U-6 Nb alloy may be lower than that measured previously by diffusion couples. Though the model, as used, did not predict the exact niobium profile in the plate, prior calculations had successfully predicted an improvement in homogeneity due to increased forging prior to homogenization. 1

\section{CONCLUSIONS}

The following conclusions have been reached as a result of this study:

1. Plates of the U-6 Nb alloy can be produced with a very uniform chemical homogeneity and a fine grain size.

2. U-6 Nb alloy exhibits a reduction in ductility at room temperature with increasing grain size.

3. Increased forging reductions, prior to homogenization, produces better chemical homogeneity than increasing time and temperature of the homogenization treatment.

4. Calculations of the effect of forging on homogeneity of rolled plate suggests that the activation energy for the diffusion of niobium may be lower in uranium-niobium alloys than previously measured. 


\section{REFERENCES}

1. Snyder, W. B.; Homogenization of Arc-Melted Uranium-6 Weight Percent Niobium Alloy Ingots, Y-2102; Union Carbide Corporation-Nuclear Division, Oak Ridge, Y-12 Plant, Oak Ridge, Tennessee; January 31, 1978.

2. Banker, J. G.; Personal Communication; Union Carbide Corporation-Nuclear Division, Oak Ridge, Y-12 Plant, Oak Ridge, Tennessee; June 1977.

3. Snyder, W. B.; Effects of Heat Treatment on the Microstructure and Mechanical Properties of Uranium-6 Niobium Alloy, Y-2134; Union Carbide Corporation-Nuclear Division, Oak Ridge Y-12 Plant, Oak Ridge, Tennessee; October 13, 1978.

4. Peterson, N. L. and Ogilvie, R. E.; Trans AIME, 227, p 1083 (1963). 


\section{Distribution}

\section{Aerospace Corporation.ARPA}

Kendall, G.

Air Force Armaments Laboratory

Wilson, L.

Air Force Materials Laboratory

Inouye, S.

\section{Battelle Memorial Institute}

Meyer, G.

Department of Energy - Oak Ridge

Hickman, H. D.

Leed, R. E.

Zachry, D. S., Jr

Lawrence Livermore Laboratory

Fulton, F. J.

Nelson, W. E.

Woods, D. H.

Los Alamos Scientific Laboratory

Hockett, J. E.

Hoyt, H. C.

Kirby, R. S.

Sandstrom, D.

Oak Ridge Gaseous Diffusion Plant

Stief, S. S.

Wilcox, W. J., Jr

Oak Ridge National Laboratory

Heestand, R. L.

Inouye, $\mathrm{H}$.

McHargue, C. J.

Ogle, J. C.

Vandermeer, R. A.

Weir, J. R., Jr

\section{Oak Ridge Y-12 Plant}

Anderson, R. C.

Beck, D. E.

Bernander, N. K.

Burditt, R. B.

Carpenter, D. A.

Cuddy, L. M.
Dodson, W. H./Googin, J. M.

Duggan, H. G.

Evans, P. A.

Ferguson, J. E.

Fraser, R. J.

Gritzner, V. B.

Haeusler, K. R.

Jackson, V. C.

Jessen, N. C., Jr

Johnson, D. H.

Jones, F. W.

Kahl, K. G.

Keith, A.

Kite, H. T.

Koger, J,W.

Kollie, T. G.

Mason, D. L.

McElroy, B. D.

Mills, J. M., Jr

Myhre, T. C.

Northcutt, W. G., Jr

Phillips, L. R.

Smith, H. F., Jr

Smith, R. D.

Snyder, W. B., Jr (10)

Stoner, H. H.

Tewes, W. E.

Thompson, J. E.

Townsend, A. B.

Walker, L. R.

White, J. C.

Yaggi, W. J.

$Y-12$ Central Files (master copy)

$Y-12$ Central Files (route copy)

$Y-12$ Central Files ( $Y$-12RC)

$Y-12$ Central Files (5)

Paducah Gaseous Diffusion Plant

Bewley, H. D.

Rockwell International - Rocky Flats

Jackson, R. J.

Mataya, $M$.

\section{Sandia - Albuquerque}

Eckelmeyer, K. H.

Magnani, N. J.'

Rohde, R. W. 
Sandia - Livermore

Adolphson, D. R.

Mote, M. W.

Union Carbide Corporation - New York

Tinsley, S. W.

US Army Armament Research and Development Command

Bloore, E. W.

US Army Ballistics Research Laboratories

Gillich, W.

US Army Materials and Mechanics Research Center

Greenspan, J.

Larson, $F$.

US Naval Weapons Laboratory

Crowe, $R$.

In addition, this report is distributed in accordance with the Category UC-25, Materials, as given in the USERDA Standard Distribution Lists for Unclassified Scientific and Technical Reports, TID-4500. 